\title{
Support for a Multidimensional Model of Study Abroad Immersion Preference
}

\author{
Susan B. Goldstein \\ University of Redlands
}

\begin{abstract}
:
Students seeking to study abroad are increasingly able to select their preferred level of immersion in such areas as program duration, similarity of classmates, language of instruction, and housing environment. As researchers endeavor to understand the relative contribution of these decisions to intercultural learning outcomes, information is needed regarding the student characteristics associated with these program choices. Questionnaire data from 252 undergraduates yielded demographic, social, personality, and intercultural predictors of preference for level of immersion across seven study abroad dimensions and supported a multidimensional model of immersion. Implications are discussed for outcome research methodology, study abroad advising, pre-departure training, and program design.
\end{abstract}

\section{Introduction}

Along with the dramatic growth in study abroad participation over the past few decades has come a marked increase in program options available to student sojourners. Students seeking to study abroad are increasingly able to select programs based on their preferred level of immersion across several dimensions, including program duration, similarity of classmate nationality, language requirements for admission, language of instruction, housing options, experiential learning opportunities, and availability of guided intercultural orientation. Lower immersion options have become increasingly available and utilized. For example, of the 325,339 U.S. students who participated in study abroad during the 2015-2016 academic year, 63\% attended short-term programs of eight weeks or less, $35 \%$ enrolled in academic quarter or semester programs, and only $2 \%$ attended academic or calendar year-long programs (Institute of International Education, 2017). In addition, many colleges and universities in the U.S. have addressed greater demand for study abroad experiences by incorporating exported campus or "island" programs into their study abroad options (Engle \& Engle, 2003; Maharaja, 2009) in which students and faculty from a single university are transported to a self-contained community within the host culture (Norris \& Dwyer, 2005). These programs typically involve relatively low levels of immersion in terms of language use and interaction with host nationals.

There is considerable debate in the study abroad community about the relationship between level of immersion in the host culture and student outcomes, such as intercultural competence and language proficiency (Fry, Paige, Jon, Dillow, \& Nam, 2009) and recent research has challenged the assumption that there is a linear relationship between immersion and culture learning (e.g., Vande Berg, Connor-Linton, \& Paige, 2009). Furthermore, several studies (e.g., Anderson, Lawton, Rexeisen, \& Hubbard, 2006; Chieffo \& Griffiths, 2004; Dwyer, 2004) have demonstrated positive outcomes for short-term study abroad experiences. Hofer, Thebodo, Meredith, Kaslow, and 
Saunders (2016, p. 27) explain, "As this paradigm is shifting, more research is being conducted on the factors that affect study abroad learning and outcomes, such as program design aspects (e.g., program length, linguistic factors, types of housing, etc.) and interventions (e.g., cultural mentoring, pre-departure and re-entry sessions, courses, and texts) ..."

As researchers strive to clarify the relationship between immersion and culture learning, attention must be given to the under investigated issue of how students view and make decisions about level of immersion in study abroad programs. This information is critical to research design in that if there are specific student attributes associated with preference for different immersion levels, this may indicate a need for multiple baselines in assessing program outcomes. For example, if students who select low immersion programs start out with relatively poor intercultural skills or language ability or aptitude, then pre-post change in outcome measures would be a more appropriate assessment than the use of absolute scores. There is some indication that individual differences associated with preference for immersion level may, in fact, exist. For example, previous research has identified personality and intercultural characteristics that differentiate students who prefer exported campus programs from those who prefer a more immersive model (Goldstein, 2015).

There are also practical implications of identifying predictors of student preferences for level of immersion. Li, Olson, and Frieze (2013) suggest that a better understanding of study abroad participants' characteristics is required for effective recruitment and program development. For example, if students' preferences for short-term programs are based primarily on financial need, this might be addressed by grants or loans to support study abroad. However, if students are selecting short-term programs due to a lack of intercultural skills or knowledge, pre-departure training might enable them to select programs with greater immersion, if desired.

Engle and Engle's (2003) classification model of study abroad program types has served as the basis of research on study abroad outcomes (e.g., Dwyer, 2004; Meyer-Lee \& Chambers, 2015) and provides a useful framework for investigating student characteristics associated with immersion preferences. This model maps seven components of study abroad (length of student sojourn, context of academic work, entry target-language competence, language used in course work, types of student housing, provisions for guided/structured cultural interaction and experiential learning, and guided reflection on cultural experiences) across five levels of immersion. The use of this model allows for a determination of whether immersion preferences are unidimensional (i.e., an overall preference for low or high immersion) or whether students' preferences depend on the study abroad program dimension in question. The current study investigated the characteristics of students who prefer varying levels of immersion across these program dimensions and was designed to address the following two research questions:

1. To what extent do demographic, social, personality, and intercultural variables predict preference for level of immersion?

2. Is there a unique set of predictors for each dimension, supporting a multidimensional model of immersion preference?

Possible predictors of immersion preference were selected based on the limited literature on study abroad program selection (e.g., Eder, Smith, \& Pitts, 2010; Goldstein, 2015; Zimmermann \& Neyer, 2013) as well as on variables associated with the likelihood of participating in study abroad 
programs (e.g., Beerkens, Souto-Otero, de Wit, \& Huisman, 2016; Luo \& Jamieson-Drake, 2015; Stroud, 2010; Whatley, 2017), and include demographic characteristics, campus involvement, study abroad exposure, adventurousness, language interest, and cultural intelligence.

\section{Demographic Variables}

In addition to gender, race/ethnicity, and financial status (e.g., Lörz, Netz, \& Quast, 2016; Luo \& Jamieson-Drake, 2015; Salisbury, Paulsen, \& Pascarella, 2011; Whatley, 2017), the following two demographic variables have been demonstrated to be relevant to study abroad participation.

\section{First generation status}

The scant available data on first generation students' engagement with study abroad points to an increased likelihood of multiple potential challenges, including financial constraints, family and work obligations, limited support for or familiarity with study abroad among family and friends, and reduced exposure to information about the procedures for and benefits of study abroad (Francis \& Janicek, 2012; Meyer-Lee, Chambers, Goldstein, \& Peifer, 2017). In addition, first generation students may be enrolled in more career-oriented, and thus less flexible, academic majors and may view the typical reasons for studying abroad, such as gaining independence and taking on new challenges, as less compelling or applicable (Francis \& Janicek, 2012). Several of these factors may influence first generation students' perspectives on level of immersion across study abroad program dimensions.

\section{Heritage language}

Beerkens, Souto-Otero, de Wit, and Huisman (2016) identified concern about foreign language skills as a barrier to study abroad participation for Erasmus students. In contrast, students who are bilingual may have less trepidation about an immersive experience that involves instruction or other interactions in a non-English environment. Thus, heritage language may be an important predictor of preference for level of immersion, particularly for language-related dimensions.

\section{Campus Involvement}

Investigations of the role of campus involvement on study abroad intentions and participation have resulted in conflicting findings. For example, based on their analysis of data from the CIRP Freshman Survey, Rust, Dhanatya, Furuto, and Kheiltash (2008) found that students with greater college involvement in social, academic, community, political, and diversity activities were more likely to intend to study abroad. Luo and Jamieson-Drake (2015) reported similar findings from their analysis of CIRP data in terms of students' intentions. However, their analysis of the CIRP Senior Survey indicated that the likelihood of actual participation in study abroad programs was negatively affected by involvement in student organizations. It may be that campus involvement does not only influence study abroad participation but may also influence level of immersion in program choice, with those involved in on-campus activities likely to prefer less immersive options, such as exported campus programs or programs of shorter duration, which may limit disruption of on-campus roles.

\section{Study Abroad Exposure}

Students gather information and opinions about the nature of study abroad from a variety of sources including their own previous travel experience and the experiences and views of family (Desruisseaux, 1998) and friends (Sweeny, 2013). Those with little exposure to study abroad may be 
less likely to participate (Beerkens, Souto-Otero, de Wit, \& Huisman, 2016). For example, Zhai and Scheer (2002) found that a third of the students they interviewed stated that knowing peers who had studied abroad positively influenced their own decision to participate. Little is known, however, about how such exposure may shape preference for study abroad immersion levels, an issue investigated in the current study.

\section{Adventurousness}

The Openness to Experience dimension of the Five Factor Model of personality has been consistently identified as an important intercultural trait (Caligiuri, 2000; Leung, Ang, \& Tan, 2014) and a predictor of participation in study abroad (Bakalis \& Joiner, 2004; Niehoff, Petersdotter, \& Freund, 2017), as it is associated with a decreased tendency to view intercultural situations as threatening (Van der Zee \& van Oudenhoven, 2013). Of the various facets of Openness to Experience, most relevant to preference for level of immersion may be adventurousness, which focuses on willingness to try new things. Li, Olson, and Frieze (2013), for example, found an association between intent to study abroad and neophilia, or desire for new experiences. In addition, students who scored higher on a measure of adventurousness were likely to prefer a more immersive model overall as compared with an exported campus program (Goldstein, 2015). Given the greater likelihood that a more immersive experience will involve encountering unfamiliar events, adventurousness may predict not only interest in study abroad, but desired degree of immersion across program dimensions.

\section{Language Interest}

Interest in language learning is associated with seeking intercultural contact and knowledge. Dwyer (2004, p. 158) found that "studying in one culture and language has led a significant number of respondents to learn more about another culture or learn another language." Individuals who express interest in language learning are more likely to participate in study abroad programs (Carlson, Burn, Useem, \& Yachimowicz, 1990; Goldstein \& Kim, 2006), prefer a more immersive model over an exported campus program (Goldstein, 2015), and attend international programs on campus and discuss international issues inside and outside of the classroom (Hembroff \& Rusz, 1993). Thus, language interest may be a key variable in predicting preference for level of immersion across study abroad program dimensions.

\section{Cultural Intelligence (CQ)}

CQ, defined as "an individual's capability to function effectively in situations characterized by cultural diversity" (Ang \& Van Dyne, 2008, p. 3), is a consistent predictor of intercultural adjustment (Leung, Ang, \& Tan, 2014; Lin, Chen, \& Song, 2012) and has been identified as one of the most promising approaches to understanding cross-cultural competence (Matsumoto \& Hwang, 2013). The CQ model comprises four subscales: (1) Metacognitive CQ - conscious cultural awareness during intercultural interactions; (2) Cognitive CQ - knowledge of cultural norms, practices, and conventions; (3) Motivational CQ - attention and energy toward cultural differences; and (4) Behavioral CQ - ability to act appropriately during intercultural interactions in terms of verbal and nonverbal behavior. Students with higher scores on Motivational and Metacognitive CQ were more likely to prefer an immersive model to an exported campus program (Goldstein, 2015). Thus, students with CQ scores indicating greater intercultural awareness, knowledge, motivation, or ability may be more comfortable selecting study abroad program features that are more immersive. 


\section{Method}

This study received Institutional Review Board (IRB) approval and all procedures (e.g., recruitment, informed consent, confidentiality, debriefing, and data storage) were in compliance with IRB regulations and APA Ethical Principles.

\section{Participants}

A total of 264 students signed up to participate in this study. In order to distinguish immersion preferences from reflections on actual immersion experiences, students who had previously participated in college-level study abroad programs were dropped from the analysis, including 6 international students and 6 domestic students. The remaining 252 respondents included 4 nonbinary, 72 male, and 176 female undergraduate students $(75.7 \%$ first year, $14.3 \%$ sophomores $6 \%$ juniors, and 4\% seniors) whose participation fulfilled an Introduction to Psychology course research requirement. They ranged in age from 18 to 23 years $(M=18.55)$ and attended a small liberal arts university in the southwestern United States. The majority of these students (80\%) lived in university housing or residence halls. At this institution approximately $50 \%$ of students participate in one of several study abroad options, including short-term faculty-led and semester or year-long programs and exported campus, direct enrollment, and hybrid programs.

This group represented a wide range of income levels and, in terms of race/ethnicity, selfidentified as White (49.6\%), Latino/a (25\%), Asian (10.7\%), Multiethnic (7.9\%), Black (3.6\%), Native American (2\%), and Middle Eastern/North African (1.2\%). Academic majors and intended majors included mathematics and social sciences (36\%), natural sciences $(24.6 \%)$, business $(17.9 \%)$, humanities $(11.2 \%)$, and undecided or other (10.3\%). A total of $29.8 \%$ of participants reported speaking a language other than English at home and 75\% had traveled outside of the United States, the majority as tourists $(62.3 \%)$.

\section{Instruments and Procedure}

Students who signed up to participate in this study were contacted via e-mail and asked to voluntarily complete an anonymous online survey. The link to the survey was included in the initial e-mail message and a follow-up reminder message. The questionnaire used in this study took approximately 30 minutes to complete and assessed basic demographic information, campus involvement, study abroad exposure, adventurousness, language interest, and cultural intelligence. Additional brief intercultural measures were also administered for purposes other than that of the current study. The wording and number of the Likert anchor labels on some of the original scales used in this study were modified slightly to create greater consistency across measures.

Demographic items

The demographic items included age, gender, race/ethnicity, year in college, academic major, heritage language, first generation status (defined as those without a parent who have completed a four-year college degree; Stephens, Townsend, Hamedani, Destin, \& Manzo, 2015), previous travel experience, and three Likert scale items assessing financial status. These latter items involved indicating family income, number of hours in weekly paid work during the school year, and the degree to which paid work helps to support the student's family. Given the relatively small sample sizes of individual racial/ethnic groups, race/ethnicity was coded for analysis in terms of white students (0) and students of color (1). Although clearly study abroad participation and outcomes 
vary across diverse ethnic/racial groups (e.g., Salisbury, Paulsen, \& Pascarella, 2011), the experience of minority status itself may be most relevant to immersion preferences in that it is associated with the development of intercultural skills that are advantageous when adjusting to unfamiliar situations (Volpone, Marquardt, Casper, \& Avery, 2018).

\section{Campus involvement}

Campus involvement was assessed with three separate multiple-choice items in which students indicated the number of hours spent weekly with other students, hours spent weekly in student organizations, and the number of campus organizations with which they were involved across categories (e.g., Greek, athletic, social justice, faith-based).

\section{Study abroad exposure}

A composite variable was developed by the author to assess study abroad exposure (Cronbach's alpha $=.70)$, consisting of ordinal items assessing the number of friends who had studied abroad and frequency with which respondents had discussed study abroad with faculty/staff, family, and peers. In a separate item, students rated the favorability of their family's views of study abroad. Higher scores indicate greater exposure and favorability, respectively.

\section{Adventurousness}

Adventurousness was assessed with a 10 -item subscale of the International Personality Item Pool Openness to Experience measure (IPIP; Goldberg et al., 2006; Cronbach's alpha = .81). Higher scores indicate greater adventurousness. Previous studies support the reliability, validity, and factor structure of this measure (Ehrhart, Roesch, Ehrhart, \& Kilian, 2008; Johnson, 2014; Lim \& Ployhart, 2006).

\section{Language interest}

Language interest was assessed with Hembroff and Rusz' (1993) Interest in Foreign Languages Scale (IFLS; Cronbach's alpha = .88), a 6 -item measure that assesses attitudes about the value of language learning. Higher scores indicate a greater value placed on language learning. The reliability and validity of this measure has been documented (Goldstein \& Kim, 2006; Hembroff \& Rusz, 1993; Kim \& Goldstein, 2005).

Cultural Intelligence (CQ)

Ang, Van Dyne, Koh, Ng, Templer, Tay, \& Chandrasekar's (2007) Cultural Intelligence Scale is a 20-item measure of cross-cultural competence, which contains the Metacognitive, Cognitive, Motivational, and Behavioral subscales. Higher scores indicate greater CQ on each subscale. There is an extensive literature supporting the reliability, validity, and factor structure of this measure (e.g., Ang, Van Dyne, Koh, Ng, Templar, Tay, \& Chandrasekar, 2007; Matsumoto \& Hwang, 2013; Van Dyne, Ang, \& Koh, 2008; Van Dyne, Ang, Ng, Rockstuhl, Tan, \& Koh, 2012). In the current study, these items yielded Cronbach's alphas of .83, .86, .84, and .89 for the Motivational, Cognitive, Metacognitive, and Behavioral subscales, respectively.

Study abroad model preference

Eight items were developed based on Engle and Engle's (2003) classification of study abroad program types to assess the dependent variables, preference for level of immersion in program duration, similarity of classmate nationality, requirements for target language competence, language 
of instruction, housing type, experiential learning opportunities, and guided cultural learning. These dimensions and the wording used to represent them vary slightly from that of the Engle and Engle model to facilitate student comprehension and interpretation. For example, the short-term program option was represented by "May Term," which is the short-term program offered at the institution attended by the survey participants. In addition, Engle and Engle's category of "context of academic work" was conceptualized as similarity of classmate nationality. Finally, Engle and Engle's single category of experiential learning opportunities was represented by two separate items (on internships and volunteer work). Students were instructed to respond to the eight items by indicating their preference for program features were they to study abroad (see Table 1).

\section{Table 1. Items Assessing Immersion for Study Abroad Program Dimensions and Percentage Response}

\section{Item}

[Duration] I would prefer:
a. A May Term program
b. A one semester program
c. A two semester (year-long) program

Percent

c. mainly with students from my host culture

I would prefer a program in which courses were taught:
a. In English only
b. In English at times and in the host country language at times
c. In the host country language only

I would prefer a housing arrangement living in a...
a. dorm, group housing, or apartment mainly with other U.S. Americans
b. dorm, group housing, or apartment with international students from various countries
c. dorm, group housing, or apartment mainly with students from your host country
d. brief homestay combined with another housing situation
e. homestay for entire study abroad period

I would be interested in having an internship in a host culture organization
a. No
b. Unsure
c. Yes

I would be interested in volunteering with a host culture organization
a. No
b. Unsure
c. Yes 
I would prefer a program that takes an approach to culture learning in which there...

a. is no specific coursework or program about the host

culture/learn on your own

$(13 \%)$

b. are optional courses or programs about the host culture

$(76 \%)$

c. are courses or programs about the host culture that are taken

by all students

\section{Results}

Average scores were calculated for each of the predictor variables and zero order correlations were computed for the predictors and the study abroad program dimensions (see Table 2).

Table 2. Correlations for Ordinal Predictor Variables and Study Abroad Dimensions

\begin{tabular}{|c|c|c|c|c|c|c|c|c|c|c|}
\hline Variable & Mean & SD & Duration & $\begin{array}{c}\text { Classmate } \\
\text { Nationality }\end{array}$ & $\begin{array}{l}\text { Language } \\
\text { Required }\end{array}$ & $\begin{array}{l}\text { Language } \\
\text { Instruct. }\end{array}$ & Housing & Intern. & Volunteer & $\begin{array}{l}\text { Cultural } \\
\text { Orient. }\end{array}$ \\
\hline 1. Income & 3.92 & 1.70 & .00 & -.05 & -.02 & -.05 & -.01 & -.03 & -.09 & .03 \\
\hline 2. Work hrs. & 1.68 & 0.88 & .07 & .11 & -.01 & -.02 & .03 & .02 & .09 & .03 \\
\hline $\begin{array}{l}\text { 3. Work } \\
\text { supports family }\end{array}$ & 1.27 & 0.60 & -.10 & .09 & .05 & .12 & .02 & .07 & .09 & .09 \\
\hline $\begin{array}{l}\text { 4. Campus org } \\
\text { hrs. }\end{array}$ & 3.00 & 1.94 & .02 & .07 & .12 & .09 & .09 & .09 & .02 & .10 \\
\hline $\begin{array}{l}\text { 5. Campus org } \\
\text { memberships }\end{array}$ & 3.02 & 1.75 & .00 & .13 & .10 & $.14^{*}$ & .08 & $.26 * *$ & $.17 * *$ & .06 \\
\hline $\begin{array}{l}\text { 6. Study abroad } \\
\text { exposure }\end{array}$ & 2.74 & 0.50 & .19 & $.19 * *$ & .12 & .09 & $.14^{*}$ & $.17 * *$ & .08 & .04 \\
\hline $\begin{array}{l}\text { 7. Family view } \\
\text { of study abroad }\end{array}$ & 5.29 & 1.11 & $.20 * *$ & .12 & $.15^{*}$ & .06 & .04 & .05 & .06 & .04 \\
\hline 8. Adventurous & 4.57 & 0.86 & $.23 * *$ & $.18 * *$ & $.19 * *$ & .03 & $.21 * *$ & $.22 * *$ & .12 & .04 \\
\hline 10. IFLS & 5.86 & 0.91 & .03 & .05 & $.31 * *$ & $.25 * *$ & $.17 * *$ & .08 & $.22 * *$ & $.18 * *$ \\
\hline 12. CQ-MOT & 5.19 & 0.88 & .09 & $.23 * *$ & $.18 * *$ & $.15^{*}$ & $.19 * *$ & $.22 * *$ & $.22 * *$ & .05 \\
\hline 13. CQ-COG & 3.71 & 1.16 & $.18 * *$ & .10 & $.17 * *$ & $.23 * *$ & $.19 * *$ & $.17 * *$ & .04 & -.04 \\
\hline 14. CQ-META & 4.96 & 0.96 & .07 & .12 & .03 & .09 & $.16^{* *}$ & .11 & $.16^{*}$ & .09 \\
\hline 15. CQ-BEH & 4.58 & 1.07 & .05 & $.13^{*}$ & .09 & .11 & $.16^{* *}$ & .11 & .11 & .09 \\
\hline
\end{tabular}

Note. Items rated on a 7-point scale; $* \mathrm{p}<.05 . * * \mathrm{p}<.01$.

Separate binary logistic regression analyses were used to determine the combination of independent variables that best predicts preferred level of study abroad immersion for each dimension. To aid interpretation, ordered response options for level of immersion on each dimension were combined to reduce responses to two categories (e.g., Meyer, 2014). Thus, the dependent variable on each dimension was basically low and high immersion. For example, to form two response categories for program duration, the three response options (May Term, semester program, and year-long program) were analyzed as short-term program (May Term; low immersion) vs. semester or longer (semester or year-long program; high immersion). This procedure was used to identify predictors of preferred level of immersion for program duration, similarity of classmate nationality, requirements for target language competence, language of instruction, housing type, and experiential learning opportunities (internship and volunteer work). It was not possible to identify predictors of preference for guided intercultural orientation due to the highly uneven distribution of responses. In addition, with the majority of students selecting the middle of three levels of immersion ( $76 \%$ for "optional courses or programs about the host culture"; see Table 1, item 8), there was no logical way to combine response options. The specific response categories used in the binary regression analyses for the other dimensions of immersion are indicated below. 
Table 3. Binary Logistic Regression Coefficients for Program Duration

\begin{tabular}{|c|c|c|c|c|c|c|c|c|}
\hline & & & & & & & \multicolumn{2}{|c|}{$95 \%$ C. I. } \\
\hline Variable & $\beta$ & S.E. & Wald & $d f$ & Sig. & $\operatorname{Exp}(\beta)$ & Lower & Upper \\
\hline Gender & .384 & .373 & 1.056 & 1 & .304 & 1.468 & .706 & 3.050 \\
\hline Student of Color & .543 & .372 & 2.129 & 1 & .145 & 1.721 & .830 & 3.570 \\
\hline First generation & -.851 & .384 & 4.903 & 1 & .027 & .427 & .201 & .907 \\
\hline Heritage language & .719 & .433 & 2.761 & 1 & .097 & 2.053 & .879 & 4.794 \\
\hline Family income & -.149 & .110 & 1.839 & 1 & .175 & .861 & .694 & 1.069 \\
\hline Work hours & .407 & .225 & 3.267 & 1 & .071 & 1.503 & .966 & 2.337 \\
\hline $\begin{array}{l}\text { Work supports } \\
\text { family }\end{array}$ & -.732 & .333 & 4.818 & 1 & .028 & .481 & .250 & .925 \\
\hline Campus org. hours & -.030 & .084 & .127 & 1 & .721 & .971 & .823 & 1.144 \\
\hline $\begin{array}{l}\text { Campus org. } \\
\text { memberships }\end{array}$ & -.081 & .091 & .802 & 1 & .370 & .922 & .772 & 1.101 \\
\hline Previous travel & -.150 & .396 & .143 & 1 & .706 & .861 & .396 & 1.872 \\
\hline $\begin{array}{l}\text { Study abroad } \\
\text { exposure }\end{array}$ & .674 & .234 & 8.279 & 1 & .004 & 1.962 & 1.240 & 3.104 \\
\hline $\begin{array}{l}\text { Family view of } \\
\text { study abroad }\end{array}$ & .400 & .149 & 7.197 & 1 & .007 & 1.492 & 1.114 & 1.998 \\
\hline Adventurousness & .677 & .236 & 8.248 & 1 & .004 & 1.969 & 1.240 & 3.126 \\
\hline IFLS & -.305 & .210 & 2.112 & 1 & .146 & .737 & .489 & 1.112 \\
\hline CQ-MOT & -.354 & .250 & 2.012 & 1 & .156 & .702 & .430 & 1.145 \\
\hline CQ-COG & .109 & .163 & .445 & 1 & .505 & 1.115 & .810 & 1.535 \\
\hline CQ-META & -.272 & .243 & 1.260 & 1 & .262 & .762 & .473 & 1.225 \\
\hline CQ-BEH & .150 & .177 & .715 & 1 & .398 & 1.162 & .821 & 1.644 \\
\hline Constant & -1.431 & 1.603 & .797 & 1 & .372 & .239 & & \\
\hline
\end{tabular}

Note. Hosmer and Lemeshow test shows $\chi 2=8.471, p>.05$ for the multivariate model. Statistically significant $P$-values are indicated by bold font.

For program duration, the dichotomous measure was constructed by combining responses $b$ and $c$, semester and yearlong programs, to contrast with $a$, short-term programs (see Table 1, item 1) and binary logistic regression analysis was conducted. A test of the full model against a constantonly model was statistically significant, indicating that the predictors as a set reliably distinguished those preferring short-term study abroad experiences from those preferring semester or yearlong programs $(\chi 2=45.463, p<.001, d f=18)$. Significant individual positive predictors of preferred duration included study abroad exposure, family view of study abroad, and adventurousness. First generation status and hours of work supporting family negatively predicted duration. The Nagelkerke's $\mathrm{R}^{2}$ indicated that the model explained $25 \%$ of the variation in preferred duration; $73 \%$ of cases overall were correctly classified (see Table 3). Thus, those who preferred programs of longer duration were less likely to be first generation students or to be engaged in paid work that assists with family expenses and were likely to have had greater exposure to study abroad, a family who views study abroad favorably, and a high adventurousness score.

The dichotomous variable for the binary logistic regression on similarity of classmate nationality was constructed by combining responses $b$ and $c$, international and host culture classmates, to contrast with a, own university classmates (see Table 1, item 2). A test of the full model against a constant-only model was statistically significant, indicating that the predictors as a set reliably distinguished those preferring classmates from their own university from those preferring international or host culture classmates $(\chi 2=47.395, p<.001, d f=18)$. Adventurousness and CQMotivation (i.e., attention and energy toward cultural differences) were positive predictors, and first generation status and family income were negative predictors of preferred classmate nationality. The Nagelkerke's $\mathrm{R}^{2}$ indicated that the model explained $25 \%$ of the variation in preferred classmate nationality; $69 \%$ of cases overall were correctly classified (see Table 4). In sum, respondents who 
preferred an academic context in which classmates are international students or members of the host culture as opposed to students at the same university were less likely to be first generation students or have low family incomes and were more likely to have high adventurousness and CQMotivation scores.

Table 4. Binary Logistic Regression Coefficients for Classmate Nationality

\begin{tabular}{|c|c|c|c|c|c|c|c|c|}
\hline \multirow[b]{2}{*}{ Variable } & \multirow[b]{2}{*}{$\beta$} & \multirow[b]{2}{*}{ S.E. } & \multirow[b]{2}{*}{ Wald } & \multirow[b]{2}{*}{$d f$} & \multirow[b]{2}{*}{ Sig. } & \multirow[b]{2}{*}{$\operatorname{Exp}(\beta)$} & \multicolumn{2}{|c|}{$95 \%$ C. I. } \\
\hline & & & & & & & Lower & Upper \\
\hline Gender & .517 & .342 & 2.281 & 1 & .131 & 1.676 & .857 & 3.277 \\
\hline Student of Color & -.478 & .359 & 1.769 & 1 & .184 & .620 & .307 & 1.254 \\
\hline First generation & -.962 & .379 & 6.439 & 1 & .011 & .382 & .182 & .803 \\
\hline Heritage language & .202 & .409 & .243 & 1 & .622 & 1.223 & .549 & 2.727 \\
\hline Family income & -.277 & .106 & 6.859 & 1 & .009 & .758 & .616 & .933 \\
\hline Work hours & .244 & .213 & 1.307 & 1 & .253 & 1.276 & .840 & 1.938 \\
\hline Work supports family & .261 & .318 & .673 & 1 & .412 & 1.298 & .696 & 2.423 \\
\hline Campus org. hours & .033 & .081 & .167 & 1 & .683 & 1.033 & .882 & 1.211 \\
\hline $\begin{array}{l}\text { Campus org. } \\
\text { memberships }\end{array}$ & .118 & .087 & 1.842 & 1 & .175 & 1.126 & .949 & 1.336 \\
\hline Previous travel & .118 & .387 & .093 & 1 & .761 & 1.125 & .527 & 2.402 \\
\hline $\begin{array}{l}\text { Study abroad } \\
\text { exposure }\end{array}$ & .399 & .213 & 3.532 & 1 & .060 & 1.491 & .983 & 2.261 \\
\hline $\begin{array}{l}\text { Family view of study } \\
\text { abroad }\end{array}$ & .193 & .145 & 1.775 & 1 & .183 & 1.213 & .913 & 1.611 \\
\hline Adventurousness & .482 & .222 & 4.732 & 1 & .030 & 1.619 & 1.049 & 2.500 \\
\hline IFLS & -.307 & .195 & 2.487 & 1 & .115 & .736 & .503 & 1.077 \\
\hline CQ-MOT & .508 & .241 & 4.448 & 1 & .035 & 1.661 & 1.037 & 2.663 \\
\hline CQ-COG & .042 & .155 & .074 & 1 & .786 & 1.043 & .770 & 1.414 \\
\hline CQ-META & -.415 & .232 & 3.187 & 1 & .074 & .661 & .419 & 1.041 \\
\hline CQ-BEH & .241 & .171 & 1.993 & 1 & .158 & 1.273 & .911 & 1.780 \\
\hline Constant & -4.506 & 1.570 & 8.243 & 1 & .004 & .011 & & \\
\hline
\end{tabular}

Note. Hosmer and Lemeshow test shows $\chi 2=10.414, p>.05$ for the multivariate model. Statistically significant $P$-values are indicated by bold font.

For requirements for target language competence, the dichotomous measure was constructed by combining responses $a$ and $b$, in which there is no target language requirement, to contrast with $c$ through $e$, in which at least some target language ability is required (see Table 1, item 3). A test of the full model against a constant-only model was statistically significant, indicating that the predictors as a set reliably distinguished those preferring no target language requirement from those preferring at least some target language requirement $(\chi 2=58.974, p<.001$, $d f=18)$. Positive predictors of preferred target language requirement included (non-English) heritage language, campus organization hours, and language interest (IFLS score). The CQ-Metacognitive score (i.e., conscious cultural awareness during intercultural interactions) was a significant negative predictor. The Nagelkerke's $\mathrm{R}^{2}$ indicated that the model explained $30 \%$ of the variation in preferred language requirement; $68 \%$ of cases overall were correctly classified (see Table 5). This analysis indicated that those who preferred programs with a target language requirement were more likely to speak a language other than English at home, were more involved in campus organizations, had higher scores on the measure of language interest (IFLS score), and had lower scores on CQMetacognitive. 
Table 5. Binary Logistic Regression Coefficients for Language Requirement

\begin{tabular}{|c|c|c|c|c|c|c|c|c|}
\hline Variable & $\beta$ & S.E. & Wald & $d f$ & Sig. & $\operatorname{Exp}(\beta)$ & Lower & Upper \\
\hline Gender & .673 & .354 & 3.608 & 1 & .057 & 1.961 & .979 & 3.927 \\
\hline Student of Color & -.441 & .372 & 1.407 & 1 & .236 & .643 & .310 & 1.333 \\
\hline First generation & .190 & .367 & .267 & 1 & .605 & 1.209 & .589 & 2.483 \\
\hline Heritage language & 1.065 & .415 & 6.571 & 1 & .010 & 2.900 & 1.285 & 6.546 \\
\hline Family income & -.063 & .107 & .344 & 1 & .557 & .939 & .761 & 1.159 \\
\hline Work hours & .285 & .216 & 1.753 & 1 & .186 & 1.330 & .872 & 2.030 \\
\hline $\begin{array}{l}\text { Work supports } \\
\text { family }\end{array}$ & -.096 & .322 & .090 & 1 & .764 & .908 & .483 & 1.706 \\
\hline Campus org. hours & .171 & .083 & 4.246 & 1 & .039 & 1.186 & 1.008 & 1.395 \\
\hline $\begin{array}{l}\text { Campus org. } \\
\text { memberships }\end{array}$ & .141 & .094 & 2.277 & 1 & .131 & 1.152 & .959 & 1.384 \\
\hline Previous travel & .364 & .398 & .836 & 1 & .361 & 1.439 & .660 & 3.138 \\
\hline $\begin{array}{l}\text { Study abroad } \\
\text { exposure }\end{array}$ & .133 & .218 & .374 & 1 & .541 & 1.142 & .746 & 1.750 \\
\hline $\begin{array}{l}\text { Family view of study } \\
\text { abroad }\end{array}$ & .237 & .149 & 2.533 & 1 & .112 & 1.267 & .947 & 1.696 \\
\hline Adventurousness & -.122 & .227 & .291 & 1 & .590 & .885 & .567 & 1.380 \\
\hline IFLS & .905 & .241 & 14.106 & 1 & .000 & 2.471 & 1.541 & 3.963 \\
\hline CQ-MOT & .118 & .240 & .241 & 1 & .624 & 1.125 & .703 & 1.801 \\
\hline CQ-COG & .318 & .164 & 3.741 & 1 & .053 & 1.374 & .996 & 1.897 \\
\hline CQ-META & -.572 & .242 & 5.574 & 1 & .018 & .564 & .351 & .907 \\
\hline CQ-BEH & .124 & .180 & .472 & 1 & .492 & 1.132 & .795 & 1.610 \\
\hline Constant & -7.818 & 1.766 & 19.591 & 1 & .000 & .000 & & \\
\hline
\end{tabular}

Note. Hosmer and Lemeshow test shows $\chi 2=8.787, p>.05$ for the multivariate model. Statistically significant $P$-values are indicated by bold font.

Table 6. Binary Logistic Regression Coefficients for Language of Instruction

$95 \%$ C. I.

\begin{tabular}{|c|c|c|c|c|c|c|c|c|}
\hline Variable & $\beta$ & S.E. & Wald & $d f$ & Sig. & $\operatorname{Exp}(\beta)$ & Lower & Upper \\
\hline Gender & .338 & .339 & .990 & 1 & .320 & 1.401 & .721 & 2.725 \\
\hline Student of Color & -.037 & .356 & .011 & 1 & .918 & .964 & .480 & 1.936 \\
\hline First generation & -.054 & .361 & .023 & 1 & .881 & .947 & .467 & 1.921 \\
\hline Heritage language & .538 & .402 & 1.794 & 1 & .180 & 1.713 & .779 & 3.768 \\
\hline Family income & .023 & .103 & .051 & 1 & .822 & 1.023 & .837 & 1.251 \\
\hline Work hours & -.141 & .217 & .421 & 1 & .516 & .869 & .568 & 1.329 \\
\hline Work supports family & .278 & .320 & .752 & 1 & .386 & 1.320 & .705 & 2.474 \\
\hline Campus org. hours & .132 & .080 & 2.749 & 1 & .097 & 1.142 & .976 & 1.335 \\
\hline $\begin{array}{l}\text { Campus org. } \\
\text { memberships }\end{array}$ & .140 & .091 & 2.380 & 1 & .123 & 1.150 & .963 & 1.373 \\
\hline Previous travel & -.357 & .382 & .875 & 1 & .350 & .700 & .331 & 1.479 \\
\hline $\begin{array}{l}\text { Study abroad } \\
\text { exposure }\end{array}$ & .176 & .210 & .703 & 1 & .402 & 1.192 & .790 & 1.799 \\
\hline $\begin{array}{l}\text { Family view of study } \\
\text { abroad }\end{array}$ & .145 & .145 & 1.008 & 1 & .315 & 1.156 & .871 & 1.535 \\
\hline Adventurousness & -.436 & .224 & 3.801 & 1 & .051 & .647 & .417 & 1.002 \\
\hline IFLS & 695 & .217 & 10.253 & 1 & .001 & 2.004 & 1.309 & 3.066 \\
\hline CQ-MOT & .115 & .235 & .241 & 1 & .624 & 1.122 & .708 & 1.779 \\
\hline CQ-COG & .429 & .158 & 7.393 & 1 & .007 & 1.536 & 1.127 & 2.094 \\
\hline CQ-META & -.532 & .235 & 5.116 & 1 & .024 & .588 & .371 & .931 \\
\hline CQ-BEH & .254 & .176 & 2.078 & 1 & .149 & 1.289 & .913 & 1.821 \\
\hline Constant & -5.247 & 1.618 & 10.517 & 1 & .001 & .005 & & \\
\hline
\end{tabular}

Note. Hosmer and Lemeshow test shows $\chi 2=11.146, p>.05$ for the multivariate model. Statistically significant $P$-values are indicated by bold font.

The dichotomous variable for the language of instruction was constructed by combining responses $b$ and $c$, in which some or all instruction takes place in the host country language, to 
contrast with $a$, instruction in English only (see Table 1, item 4). A test of the full model against a constant-only model was statistically significant, indicating that the predictors as a set reliably distinguished those preferring English only from those preferring some or all instruction in the host country language $(\chi 2=45.199, p<.001, d f=18)$. Language interest (IFLS score) and CQ-Cognitive (i.e., knowledge of cultural norms, practices, and conventions) were significant positive predictors and CQ-Metacognitive (i.e., conscious cultural awareness during intercultural interactions) was a negative predictor of preferred language of instruction. The Nagelkerke's $\mathrm{R}^{2}$ indicated that the model explained $24 \%$ of the variation in preferred language of instruction; $70 \%$ of cases overall were correctly classified (see Table 6). As compared with students who preferred coursework in English only, those who indicated a preference for a language of instruction that was partly or fully non-English scored lower on CQ-Metacognitive and higher on the language interest and CQCognitive measures.

For the Housing dimension, the homestay options were excluded from the analysis due to low numbers endorsing these items $(9 \%$ for brief homestay and $4 \%$ for homestay for the duration of study abroad). Instead, the binary regression analysis was conducted comparing the response category a, housing mainly with other U.S. Americans, with b combined with c, which included group housing with international and host country classmates (see Table 1, item 5). A test of the full model against a constant-only model was statistically significant, indicating that the predictors as a set reliably distinguished those preferring housing with other U. S. Americans from those preferring housing with international or host country students $(\chi 2=29.523, \mathrm{p}<.05$, df $=18)$. The only significant individual (positive) predictor of a more immersive housing preference was adventurousness. The Nagelkerke's R2 indicated that the model explained $18 \%$ of the variation in preferred language requirement; $66 \%$ of cases overall were correctly classified (see Table 7).

Table 7. Binary Logistic Regression Coefficients for Housing

\begin{tabular}{|c|c|c|c|c|c|c|c|c|}
\hline & & & & & & & \multicolumn{2}{|c|}{$95 \%$ C. I. } \\
\hline Variable & $\beta$ & S.E. & Wald & $d f$ & Sig. & $\operatorname{Exp}(\beta)$ & Lower & Upper \\
\hline Gender & -.006 & .344 & .000 & 1 & .985 & .994 & .506 & 1.952 \\
\hline Student of Color & -.008 & .386 & .000 & 1 & .983 & .992 & .465 & 2.114 \\
\hline First generation & -.256 & .383 & .448 & 1 & .503 & .774 & .365 & 1.639 \\
\hline Heritage language & .660 & .436 & 2.297 & 1 & .130 & 1.936 & .824 & 4.548 \\
\hline Family income & -.099 & .109 & .824 & 1 & .364 & .906 & .732 & 1.121 \\
\hline Work hours & .384 & .221 & 3.013 & 1 & .083 & 1.468 & .952 & 2.264 \\
\hline Work supports family & -.157 & .338 & .216 & 1 & .642 & .854 & .440 & 1.658 \\
\hline Campus org. hours & -.008 & .083 & .008 & 1 & .927 & .992 & .844 & 1.167 \\
\hline $\begin{array}{l}\text { Campus org. } \\
\text { memberships }\end{array}$ & -.035 & .092 & .148 & 1 & .701 & .965 & .806 & 1.156 \\
\hline Previous travel & .328 & .394 & .690 & 1 & .406 & 1.388 & .641 & 3.007 \\
\hline $\begin{array}{l}\text { Study abroad } \\
\text { exposure }\end{array}$ & .234 & .219 & 1.141 & 1 & .286 & 1.264 & .822 & 1.943 \\
\hline $\begin{array}{l}\text { Family view of study } \\
\text { abroad }\end{array}$ & .097 & .148 & .427 & 1 & .514 & 1.102 & .824 & 1.473 \\
\hline Adventurousness & .716 & .238 & 9.078 & 1 & .003 & 2.046 & 1.284 & 3.261 \\
\hline IFLS & -.042 & .192 & .049 & 1 & .825 & .958 & .658 & 1.395 \\
\hline CQ-MOT & .232 & .246 & .891 & 1 & .345 & 1.261 & .779 & 2.043 \\
\hline CQ-COG & -.019 & .164 & .014 & 1 & .907 & .981 & .711 & 1.353 \\
\hline CQ-META & -.187 & .244 & .591 & 1 & .442 & .829 & .514 & 1.337 \\
\hline CQ-BEH & .095 & .180 & .278 & 1 & .598 & 1.100 & .772 & 1.566 \\
\hline Constant & -5.037 & 1.722 & 8.559 & 1 & .003 & .006 & & \\
\hline
\end{tabular}

Note. Hosmer and Lemeshow test shows $\chi 2=11.236, p>.05$ for the multivariate model. Statistically significant $P$-values are indicated by bold font. 
Preference for immersion in terms of experiential learning was assessed with two items in which students indicated preference for an internship and for volunteer work in the host country with response items $a$ (No) and $b$ (Unsure) combined and contrasted with $c$ (Yes) for the binary logistic regression analysis (see Table 1, items 6 and 7). For internship, a test of the full model against a constant-only model was statistically significant, indicating that the predictors as a set reliably distinguished those preferring an internship from those unsure or opposed to an internship $(\chi 2=35.045, p<.01, d f=18)$. The only significant individual (positive) predictor of internship preference was campus organization memberships. The Nagelkerke's $\mathrm{R}^{2}$ indicated that the model explained $19 \%$ of the variation in internship preference; $68 \%$ of cases overall were correctly classified (see Table 8).

Table 8. Binary Logistic Regression Coefficients for Internship

\begin{tabular}{|c|c|c|c|c|c|c|c|c|}
\hline \multirow[b]{2}{*}{ Variable } & \multirow[b]{2}{*}{$\beta$} & \multirow[b]{2}{*}{ S.E. } & \multirow[b]{2}{*}{ Wald } & \multirow[b]{2}{*}{$d f$} & \multirow[b]{2}{*}{ Sig. } & \multirow[b]{2}{*}{$\operatorname{Exp}(\beta)$} & \multicolumn{2}{|c|}{$95 \%$ C. I. } \\
\hline & & & & & & & Lower & Upper \\
\hline Gender & -.318 & .331 & .927 & 1 & .336 & .727 & .381 & 1.391 \\
\hline Student of Color & -.099 & .347 & .081 & 1 & .776 & .906 & .459 & 1.789 \\
\hline First generation & -.401 & .358 & 1.251 & 1 & .263 & .670 & .332 & 1.352 \\
\hline Heritage language & .710 & .392 & 3.274 & 1 & .070 & 2.033 & .943 & 4.386 \\
\hline Family income & -.032 & .099 & .106 & 1 & .745 & .968 & .797 & 1.176 \\
\hline Work hours & .064 & .210 & .092 & 1 & .761 & 1.066 & .706 & 1.609 \\
\hline $\begin{array}{l}\text { Work supports } \\
\text { family }\end{array}$ & .302 & .317 & .910 & 1 & .340 & 1.353 & .727 & 2.517 \\
\hline Campus org. hours & .087 & .077 & 1.294 & 1 & .255 & 1.091 & .939 & 1.268 \\
\hline $\begin{array}{l}\text { Campus org. } \\
\text { memberships }\end{array}$ & .244 & .093 & 6.901 & 1 & .009 & 1.277 & 1.064 & 1.532 \\
\hline Previous travel & .246 & .376 & .427 & 1 & .513 & 1.279 & .612 & 2.672 \\
\hline $\begin{array}{l}\text { Study abroad } \\
\text { exposure }\end{array}$ & .193 & .207 & .873 & 1 & .350 & 1.213 & .809 & 1.819 \\
\hline $\begin{array}{l}\text { Family view of study } \\
\text { abroad }\end{array}$ & .007 & .140 & .003 & 1 & .957 & 1.007 & .766 & 1.325 \\
\hline Adventurousness & .276 & .211 & 1.707 & 1 & .191 & 1.318 & .871 & 1.994 \\
\hline IFLS & -.162 & .188 & .747 & 1 & .388 & .850 & .588 & 1.229 \\
\hline CQ-MOT & .256 & .230 & 1.231 & 1 & .267 & 1.291 & .822 & 2.029 \\
\hline CQ-COG & .194 & .152 & 1.627 & 1 & .202 & 1.215 & .901 & 1.637 \\
\hline CQ-META & -.368 & .225 & 2.661 & 1 & .103 & 692 & .445 & 1.077 \\
\hline CQ-BEH & .165 & .167 & .980 & 1 & .322 & 1.180 & .851 & 1.636 \\
\hline Constant & -3.516 & 1.492 & 5.553 & 1 & .018 & .030 & & \\
\hline
\end{tabular}

For volunteer work, a test of the full model against a constant-only model was statistically significant, indicating that the predictors as a set reliably distinguished those preferring volunteer work from those unsure or opposed to volunteer work $(\chi 2=37.692, p<.005, d f=18)$. Significant individual predictors of preference for volunteer work included gender (female), Student of Color, and previous travel. The Nagelkerke's $\mathrm{R}^{2}$ indicated that the model explained $23 \%$ of the variation in preference for volunteer work; $76 \%$ of cases overall were correctly classified (see Table 9). In sum, students who were involved in more campus organizations were most likely to prefer an internship while abroad, whereas preference for volunteer work was best predicted by being female, a Student of Color, and having previous travel experience. 
Table 9. Binary Logistic Regression Coefficients for Volunteer Work

\begin{tabular}{|c|c|c|c|c|c|c|c|c|}
\hline & & & & & & & \multicolumn{2}{|c|}{$95 \%$ C. I. } \\
\hline Variable & $\beta$ & S.E. & Wald & $d f$ & Sig. & $\operatorname{Exp}(\beta)$ & Lower & Upper \\
\hline Gender & -.990 & .377 & 6.891 & 1 & .009 & .371 & .177 & .778 \\
\hline Student of Color & 1.055 & .454 & 5.414 & 1 & .020 & 2.873 & 1.181 & 6.988 \\
\hline First generation & .094 & .447 & .045 & 1 & .833 & 1.099 & .458 & 2.640 \\
\hline Heritage language & -.864 & .521 & 2.747 & 1 & .097 & .422 & .152 & 1.171 \\
\hline Family income & -.117 & .121 & .937 & 1 & .333 & .890 & .702 & 1.127 \\
\hline Work hours & .350 & .251 & 1.938 & 1 & .164 & 1.419 & .867 & 2.321 \\
\hline $\begin{array}{l}\text { Work supports } \\
\text { family }\end{array}$ & -.036 & .384 & .009 & 1 & .926 & .965 & .454 & 2.050 \\
\hline Campus org. hours & .156 & .091 & 2.897 & 1 & .089 & 1.168 & .977 & 1.398 \\
\hline $\begin{array}{l}\text { Campus org. } \\
\text { memberships }\end{array}$ & .152 & .122 & 1.542 & 1 & .214 & 1.164 & .916 & 1.480 \\
\hline Previous travel & 1.015 & .436 & 5.419 & 1 & .020 & 2.759 & 1.174 & 6.485 \\
\hline $\begin{array}{l}\text { Study abroad } \\
\text { exposure }\end{array}$ & -.013 & .249 & .003 & 1 & .957 & .987 & .605 & 1.608 \\
\hline $\begin{array}{l}\text { Family view of study } \\
\text { abroad }\end{array}$ & .122 & .168 & .530 & 1 & .467 & 1.130 & .814 & 1.569 \\
\hline Adventurousness & -.256 & .259 & .976 & 1 & .323 & .774 & .465 & 1.287 \\
\hline IFLS & .312 & .212 & 2.172 & 1 & .141 & 1.366 & .902 & 2.067 \\
\hline CQ-MOT & .420 & .287 & 2.153 & 1 & .142 & 1.523 & .868 & 2.670 \\
\hline CQ-COG & -.016 & .188 & .008 & 1 & .930 & .984 & .681 & 1.421 \\
\hline CQ-META & .029 & .271 & .011 & 1 & .916 & 1.029 & .605 & 1.751 \\
\hline CQ-BEH & .126 & .214 & .345 & 1 & .557 & 1.134 & .746 & 1.725 \\
\hline Constant & -4.409 & 1.863 & 5.603 & 1 & .018 & .012 & & \\
\hline
\end{tabular}

Note. Hosmer and Lemeshow test shows $\chi 2=6.252, p>.05$ for the multivariate model. Statistically significant $P$-values are indicated by bold font.

\section{Discussion}

The results of this study support the notion put forth by Engle and Engle (2003) that study abroad immersion is a multidimensional phenomenon in that preference for immersion on each dimension was associated with a unique set of student characteristics. Those who preferred programs of longer duration were likely to have had greater exposure to study abroad, a family that views study abroad favorably, and a high adventurousness score and were less likely to be first generation students or to be engaged in paid work that assists with family expenses. Students who preferred international or host culture classmates rather than students from their own university were more likely to have high adventurousness and CQ-Motivation scores (i.e., attention and energy toward cultural differences) and less likely to be first generation students or have low family incomes. More immersive housing preferences were predicted only by higher adventurousness scores. Adventurousness, while central to forms of immersion dealing with program duration, classmate nationality, and housing, was unrelated to language-related immersion preferences. Those who preferred programs with a target language requirement were more likely to speak a language other than English at home, were more involved in campus organizations, had higher scores on the measure of language interest (IFLS score), and had lower scores on CQ-Metacognitive (i.e., conscious cultural awareness during intercultural interactions). As compared with students who preferred coursework in English only, those who indicated a preference for a language of instruction that was partly or fully non-English scored higher on the language interest and CQ-Cognitive (i.e., knowledge of cultural norms, practices, and conventions) measures and lower on CQ-Metacognitive. Finally, students who preferred an internship while abroad were involved in more campus organizations and those who preferred volunteer work tended to be female, Students of Color, and have had previous travel experience. These findings have important implications for research on 
study abroad outcomes as well as for advising and recruitment, home campus programming, predeparture training, and program design.

The multidimensional nature of study abroad immersion should be a consideration when designing and interpreting outcome research. Investigations of study abroad outcomes are frequently dependent upon retrospective surveys or outcome measures that are administered only at the conclusion of the program (Varela, 2017). The results of such assessments should be interpreted with caution. It is well established that students who choose to study abroad differ in significant ways from those who do not (Goldstein \& Kim, 2006; Luo \& Jamieson-Drake, 2015; Salisbury, Paulsen, \& Pascarella, 2011). The current study extends these findings and indicates that among those intending to study abroad, there are important pre-existing differences between students preferring varying levels of immersion — and that the specific student characteristics associated with immersion preference differ for each study abroad program dimension (e.g., duration, housing, language requirements). Failure to recognize these pre-existing differences may result in erroneous conclusions about the source of study abroad outcomes. For example, imagine that researchers seeking to assess the impact of level of immersion on second language learning find that students emerge from more immersive programs with stronger language ability than do those who studied in less immersive programs. They might conclude that greater immersion is preferable for second language learning. However, if we consider that (1) students with stronger second language grammar ability prior to study abroad tend to show greater gains in grammar and oral proficiency during study abroad (Brewer, Shively, Gozik, Doyle, \& Savicki, 2015), and (2) those with stronger second language skills are likely to choose a more immersive program, we would conclude instead that preexisting differences in language ability explain the second language gains. The findings of the current study clearly indicate the need for appropriate comparison groups, pre-test measures, and the use of multiple baselines in assessing study abroad outcomes.

The multidimensional framework supported by this study may also be useful in clarifying some of the inconsistencies in research findings on the relationship between immersion and culture learning. Each of the immersion dimensions likely serves as a proxy for critical intercultural experiences (e.g., level of contact with host nationals, degree of host language use, encounters with ideas and practices that challenge ethnocentric perspectives). For example, it is not the program duration per se that we expect to yield specific programs outcomes, but the depth of intercultural experiences that is expected to increase with program duration. The multidimensional model allows for a parsing out of these relationships within the overall correlation between immersion and culture learning. It is possible that immersion level for some of the dimensions may in fact closely equate to depth of intercultural experience but for other dimensions it may not. For example, level of housing immersion may parallel level of intercultural experience in that housing with host nationals is likely to provide for greater intercultural contact than housing with same university peers. In contrast, duration of program may be less closely tied to intercultural contact; a student who is unmotivated or unequipped for intercultural contact in a summer program may be no more likely to attain that contact should he or she enroll in a semester or yearlong program. By investigating the depth of intercultural experiences associated with individual dimensions of immersion, researchers may gain a more sophisticated understanding of the relationship between level of immersion and study abroad outcomes. 
The multidimensional model of immersion may also be a useful framework for study abroad advising sessions in that it allows students to more clearly sort through the features of different programs and to more intentionally select programs that meet their individual needs and preferences. In addition, advisement based on this model may provide students with more specific and accurate expectations of their experience abroad, which is of particular importance given the role that expectation-experience congruence plays in sojourner satisfaction (Caligiuri, Phillips, Lazarova, Tarique, \& Bürgi, 2001; Martin, Bradford, \& Rohrlich, 1995; Templer, Tay, \& Chandrasekar, 2006). Those involved in advising and recruitment might also consider how specific student characteristics could influence decisions about program choice. For example, in the current study, first generation status and income-related factors most strongly influenced the preference for programs of shorter duration and for programs with same university classmates. This may reflect not only financial constraints but a lack of study abroad exposure, a variable that significantly predicted preference for program duration and approached significance in predicting similarity of classmate nationality. If post-secondary institutions seek greater enrollment in semester or yearlong programs, this might be addressed by targeted financial aid as well as greater outreach to students and their families about the nature and benefits of study abroad.

Home campus programming might also attend to the student characteristics associated with immersion on different study abroad program dimensions. For example, in contrast to the predictors of program duration and classmate nationality, language-related immersion (target language requirements and language of instruction) was strongly influenced by language interest and heritage language ability. There is much that post-secondary institutions can do to promote a campus culture in which language learning is valued, ranging from formal language requirements to language-based residence halls and activities, joint events with members of the local international community, bilingual university publications and web resources, and the use of language across the curriculum, an approach in which selected courses outside of language departments (e.g., art, history, politics) are taught in the target language (Bettencourt, 2011). Such efforts may create conditions that result in greater ease with language-immersive study abroad experiences.

The multidimensional model of immersion preference provides guidance for pre-departure orientation content in that knowledge of these separate dimensions can aid students in planning strategies for intercultural adjustment and identifying opportunities for intercultural learning, both objectives of pre-departure training (Martin, 1989). For example, if a student is cognizant of which aspects of their study abroad program are more immersive, he or she can investigate and become familiar with targeted coping strategies (e.g., for immersive housing as opposed to immersive language). In addition, some of the student characteristics associated with preference for greater immersion might be enhanced by pre-departure training and features of study abroad program design. For example, adventurousness was a predictor of preference for immersion across several dimensions, including duration, similarity of classmate nationality, and housing. Although research indicates that adventurousness, as a facet of the Openness to Experience trait, is relatively stable (Roberts \& DelVecchio, 2000) and may even have a genetic component (Heck et al., 2009), it is possible to create assignments and activities in pre-departure training and in-country programming that support students in having positive experiences in unfamiliar situations (e.g., Paige, Cohen, Kappler, Chi, \& Lassegard, 2006). This may enable students with lower levels of adventurousness to select and succeed in more immersive study abroad options, if desired. 
Research indicates that cultural intelligence can also be significantly enhanced through intercultural training and structured experiences (e.g., Earley \& Peterson, 2004; Ng, Van Dyne, \& Ang, 2009; Şahin, Gurbuz, \& Köksal, 2014), which could be integrated into pre-departure and in-country programming. The CQ-Motivation and Cognitive subscales were correlated with several of the immersion dimensions and CQ-Motivation was a significant predictor of preference for diverse classmate nationalities. Thus, it may be worthwhile to implement programs that boost these aspects of CQ as a means of equipping students with the intercultural skills needed for a more immersive experience. It is not clear why CQ-Metacognitive, in the current study, was a negative predictor of language-related immersion as this relationship was not evident in the correlational analysis. Additional research is needed to explore the role of CQ-Metacognitive in language-related immersion and to determine whether this finding may be an artifact of the intercorrelations among CQ subscales.

Home campus programming, pre-departure training, and in-country program design can play a role in facilitating student involvement in experiential learning opportunities abroad. Preference for an internship abroad was best predicted by current involvement in campus activities, perhaps because these activities provide practice in the practical and interpersonal skills students associate with an internship placement. Preference for volunteer work was predicted by gender, race/ethnicity, and travel experience. Cruce and Moore (2007) report that in their analysis of data from the U.S. National Survey of Student Engagement (NSSE), female students and African American, Latino/a, and Asian American students were more likely than White male students to volunteer during their first year of college. Previous travel was also a predictor of preference for volunteer work. It is possible that many of the students who had previous travel experience did so in a community service capacity, although that was not assessed in the current study. With deliberate efforts to prepare students for experiential learning opportunities abroad and to familiarize them with the benefits of such programs, it may be possible to involve a more diverse population of study abroad participants in these activities if desired.

\section{Limitations and Future Research}

The primary weakness of this study is its reliance on student preferences rather than the actual choices students have made in selecting study abroad programs. An alternative strategy for future research might be to assess pre-departure characteristics of students enrolled in various study abroad programs and use the Engle and Engle model to categorize those programs by level of immersion (e.g., Meyer-Lee \& Chambers, 2015). This information could then be used to identify patterns of student characteristics associated with level of immersion in each study abroad program dimension. Such studies should include respondents from a variety of institutions, as the participants in this study were drawn from a single liberal arts university in the southwestern United States, which may be unrepresentative of U.S. post-secondary institutions in level of diversity and access to study abroad programs.

In the current study, data from several ethnic/racial groups were pooled in line with research on the relationship between intercultural skills and home country minority status and to maximize sample sizes for analysis. Ideally, future research would allow for separate comparisons that acknowledge the unique experiences of U. S. ethnic/racial groups abroad. 
In terms of the measures used in this study, it is not certain that the student participants perceived the hierarchy of program features outlined in the Engle and Engle model as indicating the intended, successive levels of immersion (for example, placing studying with international students as less immersive than studying with host nationals). It might be helpful to have student participants rank study abroad program features in terms of level of immersion and then use these categories in subsequent research. This might be particularly useful in assessing perceptions of guided cultural orientation, as in the current study the majority of participants selected a single level of immersion.

It was not possible to identify predictors of preference for homestay due to the lack of participants in the current study who selected that option. As researchers seek to better understand student perceptions and outcomes of the homestay experience (e.g., Kendall-Smith \& Rich, 2003; Rodriguez \& Chornet-Roses, 2014), identifying the characteristics of students who seek this option will be critical. Future research might incorporate qualitative methodology to explore students' expectations of and concerns about the homestay experience.

Finally, there may be variables that mediate the effect of student characteristics on preference for level of immersion, and which should be investigated, such as perceived cultural distance (Varela, 2017; Wilson, Ward, \& Fischer, 2013), host culture diversity (Wilkenson, 1998), and salience of the students' race/ ethnicity in the host culture (Goldstein, 2017). As selecting among programs becomes an increasingly complex endeavor, a better understanding of the characteristics and perceptions of the students making these choices will aid researchers and practitioners seeking to enrich the culture learning experiences of those studying abroad.

\section{References}

Anderson, P. H., Lawton, L., Rexeisen, R. J., \& Hubbard, A. C. (2006). Short-term study abroad and intercultural sensitivity: A pilot study. International Journal of Intercultural Relations, 30(4), 457469

Ang, S., \& Van Dyne, L., (2008). Conceptualization of cultural intelligence: Definition, distinctiveness, and nomological network. In S. Ang, \& L. Van Dyne (Eds.), Handbook on cultural intelligence: Theory, measurement and applications (pp. 3-15). Armonk, NY: M.E. Sharpe.

Ang, S., Van Dyne, L., Koh, C., Ng, K. Y., Templer, K. J., Tay, C., \& Chandrasekar, N. A. (2007). Cultural Intelligence: Its measurement and effects on cultural judgment and decision making, cultural adaptation, and task performance. Management and Organization Review, 3(3), 335-371.

Bakalis, S., \& Joiner, T. A. (2004). Participation in tertiary study abroad programs: The role of personality. The International Journal of Educational Management, 18(4/5), 286-291.

Beerkens, M., Souto-Otero, M., de Wit, H., \& Huisman, J. (2016). Similar students and different countries? An analysis of the barriers and drivers for Erasmus participation in seven countries. Journal of Studies in International Education, 20(2), 184-204.

Bettencourt, M. (2011). Languages across the curriculum: A response to internationalization in foreign language education. Multicultural Education, 19(1), 55-58.

Brewer, E., Shively, R., Gozik, N., Doyle, D. M., \& Savicki, V. (2015). Beyond the study abroad industry: Perspectives from other disciplines on assessing study abroad learning outcomes. In V. Savicki \& E. Brewer (Eds.), Assessing study abroad: Theory, tools, and practice (pp. 33-56). Sterling, VA: Stylus.

Caligiuri, P. M. (2000). Selecting expatriates for personality characteristics: A moderating effect of personality on the relationship between host national contact and cross-cultural adjustment. MIR: Management International Review, 40(1), 61-80. 
Caligiuri, P., Phillips, J., Lazarova, M., Tarique, I., \& Burgi, P. (2001). The theory of met expectations applied to expatriate adjustment: The role of cross-cultural training. International Journal of Human Resource Management, 12(3), 357-372.

Carlson, J. S., Burn, B. B., Useem, J., \& Yachimowicz, D. (1990). Study abroad: The experience of American undergraduates. New York, NY: Greenwood.

Chieffo, L., \& Griffiths, L. (2004). Large-scale assessment of student attitudes after a short-term study abroad program. Frontiers: The Interdisciplinary Journal of Study Abroad, 10, 165-177.

Cruce, T. M., \& Moore, J. V. (2007). First-year students' plans to volunteer: An examination of the predictors of community service participation. Journal of College Student Development, 48(6), 655673.

Desruisseaux, P. (1998). What parents should know about study-abroad programs. Chronicle of Higher Education, 44(40), 1.

Dwyer, M. M. (2004). More is better: The impact of study abroad program duration. Frontiers: The Interdisciplinary Journal of Study Abroad, 10, 151-163.

Earley, P. C., \& Peterson, R. S. (2004). The elusive cultural chameleon: Cultural intelligence as a new approach to intercultural training for the global manager. Academy of Management Learning \& Education, 3(1), 100-115.

Eder, J., Smith, W. W., \& Pitts, R. E. (2010) Exploring factors influencing student study abroad destination choice. Journal of Teaching in Travel \& Tourism, 10(3), 232-250.

Ehrhart, K. H., Roesch, S. C., Ehrhart, M. G., \& Kilian, B. (2008). A test of the factor structure equivalence of the 50-Item IPIP Five-Factor Model measure across gender and ethnic groups. Journal of Personality Assessment, 90(5), 507-516.

Engle, L., \& Engle, J. (2003). Study abroad levels: Toward a classification of program types. Frontiers: The Interdisciplinary Journal of Study Abroad, 9, 1-20.

Francis, J., \& Janicek, A. (2012). Engaging first-generation college students in study abroad. Paper presented at the NAFSA Bi-regional conference, Puerto Rico.

Fry, G. W., Paige, R. M., Jon, J.-E., Dillow, J., \& Nam, K.-A. (2009). Study abroad and its transformative power. Occasional Papers on International Educational Exchange 32. Portland, ME: Council on International Educational Exchange.

Goldberg, L. R., Johnson, J. A., Eber, H. W., Hogan, R., Ashton, M. C., Cloninger, C. R., \& Gough, H. C. (2006). The International Personality Item Pool and the future of public-domain personality measures. Journal of Research in Personality, 40, 84-96.

Goldstein, S. B. (2015). Predictors of preference for the exported campus model of study abroad. Frontiers: The Interdisciplinary Journal of Study Abroad, 26, 1-16.

Goldstein, S. B. (2017). Stereotype threat in U.S. students abroad: Negotiating American identity in the age of Trump. Frontiers: The Interdisciplinary Journal of Study Abroad, 29(2), 94-108.

Goldstein, S. B., \& Kim, R. I. (2006). Predictors of U.S. college students' participation in study abroad programs: A longitudinal study. International Journal of Intercultural Relations, 30, 507-521.

Heck, A., Lieb, R., Ellgas, A., Pfister, H., Lucae, S., Roeske, D., . . Ising, M. (2009). Investigation of 17 candidate genes for personality traits confirms effects of the HTR2A gene on novelty seeking. Genes, Brain \& Behavior, 8(4), 464-472.

Hembroff, L. A., \& Rusz, D. L. (1993). Minorities and overseas studies programs: Correlates of differential participation. Occasional Papers on International Educational Exchange: Research Series 30. New York, NY: Council on International Educational Exchange.

Hofer, B. K., Thebodo, S. W., Meredith, K., Kaslow, Z., \& Saunders, A. (2016). The long arm of the digital tether: Communication with home during study abroad. Frontiers: The Interdisciplinary Journal of Study Abroad, 28, 24-41.

Institute of International Education. (2017). Open Doors report on international educational exchange. Retrieved from https://www.iie.org/Research-and-Insights/Open-Doors

Johnson, J. A. (2014). Measuring thirty facets of the Five Factor Model with a 120-item public domain inventory: Development of the IPIP-NEO-120. Journal of Research in Personality, 51, 78-89. 
Kendall-Smith, M., \& Rich, P. (2003). Satisfactions and dissatisfactions of homestay hosts with sojourn students. New Zealand Journal of Educational Studies, 38(2), 165-177.

Kim, R. I., \& Goldstein, S. B. (2005). Intercultural attitudes predict favorable study abroad expectations of American college students. Journal of Studies in International Education, 9, 265-278.

Leung, K., Ang, S., \& Tan, M. L. (2014). Intercultural competence. Annual Review of Organizational Psychology and Organizational Behavior, 1, 489-519.

Li, M., Olson, J. E., \& Frieze, I. H. (2013). Students' study abroad plans: The influence of motivational and personality factors. Frontiers: The Interdisciplinary Journal of Study Abroad, 23, 73-89.

Lim, B.-C., \& Ployhart, R. E. (2006). Assessing the convergent and discriminant validity of Goldberg's International Personality Item Pool: A multitrait-multimethod examination. Organizational Research Methods, 9, 29-54.

Lin, Y., Chen, A. S., \& Song, Y. (2012). Does your intelligence help to survive in a foreign jungle? The effects of cultural intelligence and emotional intelligence on cross-cultural adjustment. International Journal of Intercultural Relations, 36(4), 541-552.

Lörz, M., Netz, N., \& Quast, H. (2016). Why do students from underprivileged families less often intend to study abroad? Higher Education: The International Journal of Higher Education Research, 72(2), 153-174.

Luo, J., \& Jamieson-Drake, D. (2015). Predictors of study abroad intent, participation, and college outcomes. Research in Higher Education, 56(1), 29-56.

Maharaja, G. G. (2009). An "island" study abroad program and its impact on the intercultural sensitivity and cross-cultural adaptability of its participants: Perspectives from a research intensive university. (Doctoral dissertation). Retrieved from ProQuest Dissertations and Theses database. (815958894; ED512764)

Martin, J. N. (1989). Predeparture orientation: Preparing college sojourners for intercultural interaction. Communication Education, 38, 249-258.

Martin, J. N., Bradford, L., \& Rohrlich, B. (1995). Comparing predeparture expectations and post-sojourn reports: A longitudinal study of U.S. students abroad. International Journal of Intercultural Relations, 19, 87-110.

Matsumoto, D., \& Hwang, H. C. (2013). Assessing cross-cultural competence: A review of available tests. Journal of Cross-Cultural Psychology, 44(6), 849-873.

Meyer, J. P. (2014). Applied measurement with JMetrik. New York, NY: Routledge.

Meyer-Lee, E., \& Chambers, K. (2015). Using data for improvement and advocacy: A 10 year retrospective on outcomes assessment through multimethod longitudinal studies and institutional data. In V. Savicki, \& E. Brewer (Eds.), Assessing study abroad (pp. 214-227). Sterling, VA: Stylus.

Meyer-Lee, E., Chambers, K., Goldstein, S. B., \& Peifer, J. (2017, March). Research into action: Implications of student identity for education abroad. The Forum on Education Abroad. Seattle, WA.

Ng, K. Y., Van Dyne, L., \& Ang, S. (2012). Cultural intelligence: A review, reflections, and recommendations for future research. In A. M. Ryan, F.T.L. Leong, \& F. L. Oswald (Eds.), Conducting multinational research: Applying organizational psychology in the workplace (pp. 2958). Washington, DC: American Psychological Association.

Niehoff, E., Petersdotter, L., \& Freund, P. A. (2017). International sojourn experience and personality development: Selection and socialization effects of studying abroad and the big five. Personality and Individual Differences, 112, 55-61.

Norris, E. M., \& Dwyer, M. (2005). Testing assumptions: The impact of two study abroad program models. Frontiers: The Interdisciplinary Journal of Study Abroad, 11, 121-142.

Paige, R. M., Cohen, A. D., Kappler, B., Chi, J. C., \& Lassegard, J. P. (2006). Maximizing study abroad: A student's guide to strategies for language and culture learning and use (2nd ed.). Minneapolis, MN: Center for Advanced Research on Language Acquisition, University of Minnesota.

Roberts, B. W., \& DelVecchio, W. F. (2000). The rank-order consistency of personality traits from childhood to old age: A quantitative review of longitudinal studies. Psychological Bulletin, 126(1), 325 . 
Rodriguez, S. R., \& Chornet-Roses, D. (2014). How 'family' is your host family?: An examination of student-host relationships during study abroad. International Journal of Intercultural Relations, 39, 164-174.

Rust, V., Dhanatya, C., Furuto, L. H. L., \& Kheiltash, O. (2008). Student involvement as predictive of college freshmen plans to study abroad. Frontiers: The Interdisciplinary Journal of Study Abroad, $15,1-16$.

Şahin, F., Gurbuz, S., \& Köksal, O. (2014). Cultural intelligence (CQ) in action: The effects of personality and international assignment on the development of CQ. International Journal of Intercultural Relations, 39, 152-163.

Salisbury, M. H., Paulsen, M. B., \& Pascarella, E. T. (2011). Why do all the study abroad students look alike? Applying an integrated student choice model to explore differences in the factors that influence white and minority students' intent to study abroad. Research in Higher Education, 52, 123-150.

Stephens, N. M., Townsend, S. S. M., Hamedani, M. G., Destin, M., \& Manzo, V. (2015). A differenceeducation intervention equips first-generation college students to thrive in the face of stressful college situations. Psychological Science, 26(10), 1556-1566.

Stroud, A. H. (2010). Who plans (not) to study abroad? An examination of U.S. student intent. Journal of Studies in International Education, 14(5), 491-507.

Sweeney, K. (2013). Inclusive excellence and underrepresentation of students of color in study abroad. Frontiers: The Interdisciplinary Journal of Study Abroad, 23, 1-21.

Templer, K. J., Tay, C., \& Chandrasekar, N. A. (2006). Motivational cultural intelligence: Realistic job preview, realistic living conditions preview, and cross-cultural adjustment. Group and Organization Management, 31, 154-173.

Vande Berg, M., Connor-Linton, J., \& Paige, R. M. (2009). The Georgetown Consortium Project: Interventions for students learning abroad. Frontiers: The Interdisciplinary Journal of Study Abroad, $18,1-75$.

Van der Zee, K., \& van Oudenhoven, J. P. (2013). Culture shock or challenge? The role of personality as a determinant of intercultural competence. Journal of Cross-Cultural Psychology, 44(6), 928-940.

Van Dyne, L., Ang, S., \& Koh, C. (2008). Development and validation of the CQS: The cultural intelligence scale. In S. Ang \& L. Van Dyne (Eds.), Handbook on cultural intelligence: Theory, measurement and applications (pp. 16-38). Armonk, NY: M.E. Sharpe.

Van Dyne, L., Ang, S., Ng, K.-Y., Rockstuhl, T., Tan, M. L., \& Koh, C. (2012). Sub-dimensions of the four factor model of cultural intelligence: Expanding the conceptualization and measurement of cultural intelligence (CQ). Social and Personal Psychology: Compass, 6/4, 295-313.

Varela, O. E. (2017). Learning outcomes of study-abroad programs: A meta-analysis. Academy of Management Learning \& Education, 16(4), 531-561.

Volpone, S. D., Marquardt, D. J., Casper, W. J., \& Avery, D. R. (2018). Minimizing cross-cultural maladaptation: How minority status facilitates change in international acculturation. Journal of Applied Psychology, 103(3), 249-269.

Whatley, M. (2017). Financing study abroad: An exploration of the influence of financial factors on student study abroad patterns. Journal of Studies in International Education, 21(5), 431-449.

Wilkinson, S. (1998). On the nature of immersion during study abroad: Some participant perspectives. Frontiers: The Interdisciplinary Journal of Study Abroad, 4, 121-138.

Wilson, J., Ward, C., \& Fischer, R. (2013). Beyond culture learning theory: What can personality tell us about cultural competence? Journal of Cross-Cultural Psychology, 44(6), 900-927.

Zhai, L., \& Scheer, S. D. (2002). Influence of international study abroad programs on agricultural college students. Journal of International Agricultural and Extension Education, 9(3), 23-29.

Zimmermann, J., \& Neyer, F. J. (2013). Do we become a different person when hitting the road? Personality development of sojourners. Journal of Personality and Social Psychology, 105(3), 515530. 